\title{
Characteristics of Diadochokinesis in Typically Developing Children and Adults
}

\author{
Jisu Jang ${ }^{1}$, Yu Gyeong Choe', Seunghee $\mathrm{Ha}^{2}$ \\ ${ }^{1}$ Graduate Program in Speech Language Pathology, Hallym University, Chuncheon, Korea \\ ${ }^{2}$ Division of Speech Pathology and Audiology, Audiology and Speech Pathology Research Institute, Hallym University, Chuncheon, Korea
}

\author{
Received: September 20, 2020 \\ Revised: October 30, 2020 \\ Accepted: November 17, 2020 \\ Correspondence: \\ Seunghee $\mathrm{Ha}, \mathrm{PhD}$ \\ Division of Speech Pathology and \\ Audiology, Audiology and \\ Speech Pathology Research Institute, \\ Hallym University, \\ 1 Hallymdaehak-gil \\ Chuncheon 24252, Korea \\ Tel: $+82-33-248-2215$ \\ Fax: +82-33-256-3420 \\ E-mail: shha@hallym.ac.kr
}

\begin{abstract}
Purpose: The purpose of this study was to examine the characteristics of the rate and perceptual judgment of diadochokinesis (DDK) in typically developing children and adults. Methods: Participants were typically developing children aged 2;6 to 9;11 and normal adults. For DDK tasks, they were asked to repeat $\left[p^{\star} a\right],\left[t^{\star} a\right],\left[k^{\star} a\right],\left[p^{\star} a t^{\star} a\right]$, and $\left[p^{\star} a t^{\star} a k^{\star} a\right]$ accurately and quickly with one breath. The number of repetitions per second was measured as DDK rate for each stimuli. The perceptual judgment of DDK were also performed in terms of regularity, rate, and accuracy using a three-point scale. Results: Children showed increases in the number of repetitions per second for all the DDK tasks with age. However, all the children groups between ages 2;6 and 9:11 exhibited significantly slower DDK rates than adults. In the perceptual judgment of DDK tasks, accuracy, rate, and consistency of sequential motion rates using $\left[p^{*} a t^{*} a\right]$ and $\left[p^{*} a t^{*} a k^{*} a\right]$ showed statistically significant differences across age groups. Children demonstrated similar accuracy of SMR tasks with adults after age $6 ; 0$. Conclusion: This study showed developmental patterns of speech motor skills based on rate, accuracy, and consistency of DDK tasks. This study provides references for assessing speech motor skills related to children with speech difficulties.
\end{abstract}

Key Words: Developmental patterns, Diadochokinesis, Perceptual judgment, Speech motor skills.

\section{INTRODUCTION}

정상적으로 말을 산출하기 위해서는 호흡, 발성, 공명, 조음, 운율과 같은 말 산출의 하위 기제 간에 협응과 역동적인 움직 임이 필요하다. 그러나 마비말장애, 말실행증 등 신경학적 손상 으로 인한 말운동장애나 말운동문제에 기인한 말소리장애를 보이는 아동과 성인의 경우는 말 산출기관의 협응 및 움직임상 에 어려움을 보인다. 말장애를 평가하는 임상현장에서 말운동 기술을 살펴보는 대표적인 과제로 조음교대운동(diadochokinesis, DDK)이 있다. 조음교대운동(DDK)은 조음기관의 움직 임, 속도, 정확성, 일관성, 협응도를 종합적으로 살펴볼 수 있다. 또한 호흡, 발성, 공명과 같은 다른 말 산출 하위 기제 간의 협 응 정도를 동시에 파악할 수 있기 때문에 성인 말운동장애뿐만 아니라 아동 말소리장애를 감별 진단할 수 있는 과제로 유용하 다. DDK 과제에는 1음절 자음-모음(consonant-vowel, CV)구 조를 반복하는 교대운동속도(alternating motion rate, AMR)

(c) This is an Open Access article distributed under the terms of the Creative Commons Attribution Non-Commercial License (https://creativecommons.org/licenses/by-nc/4.0) which permits unrestricted non-commercial use, distribution, and reproduction in any medium, provided the original work is properly cited.
와 조음점이 서로 다른 2 3음절을 반복적으로 산출하는 일련 운동속도(sequential motion rate, SMR)가 있다. 일반적으로 초당 음절 반복 횟수를 토대로 AMR과 SMR을 측정하고 보고 한다. 말장애 평가에 있어서 DDK 과제의 유용성으로 인해 국 내외적으로 많은 연구가 일반 아동과 성인을 대상으로 발달적 특성과 규준을 제시하고 있다.

아동을 대상으로 $\mathrm{DDK}$ 의 수행력을 살펴본 대부분의 선행 연 구는 연령이 증가함에 따라 $\mathrm{DDK}$ 수행력이 증가함을 보고하고 있다(Baken \& Orlikoff, 2000; Canning \& Rose, 1974; Fletcher, 1972; Kim \& Kim, 2016; Kim et al., 2018; Robbins \& Klee, 1987; Sehr, 2013; Williams \& Stackhouse, 2000; Yoo, 2018; Yoss \& Darley, 1974). 대표적으로 국내 연구로 Yoo(2018)는 조 음 문제가 없는 만 4 6세 아동 총 248명을 대상으로 [퍼], [터], [커]를 사용하여 연령과 성별에 따른 $\mathrm{AMR}$ 의 차이를 살펴보았 다. 그 결과 성별에 따른 $\mathrm{AMR}$ 은 유의미한 차이가 없었지만, 학 령전기 아동에서 연령이 높아짐에 따라 AMR이 유의하게 증가 하는 것으로 나타났다. Sehr(2013)도 4 6세 아동을 대상으로 $\mathrm{DDK}$ 를 살펴보았는데 초당 반복 횟수뿐만 아니라 $\mathrm{DDK}$ 과제 수행 시 아동이 보이는 조음 오류 빈도와 유형, 규칙성을 분석 
하였다. 연구 결과, DDK 과제의 초당 반복 횟수는 4세와 6세 간 유의미한 차이를 보였고, 조음 오류 빈도는 4세 아동이 5 세와 6 세 아동에 비해 유의미하게 높았다. 조음 오류 유형으로는 이완 음화와 경음화가 가장 빈번하게 나타나 DDK 과제에 사용된 파 열 기식음의 발성 유형 측면에서 어려움을 보이는 것으로 나타났 다. DDK 과제의 규칙성 면에서 4 6세 간 유의미한 차이를 보이 지 않았다. 한편 국외 연구로 Williams \& Stackhouse(2000)도 $3 \sim 5$ 세 정상적인 발달을 보이는 아동 30 명을 대상으로 2 3음절 의 DDK 과제를 이용하여 속도뿐만 아니라 자극 유형과 음절 길이에 따른 정확성과 일관성을 측정하였다. 연구 결과를 살펴 보면 연령이 증가함에 따라 반응의 정확도가 증가하였지만 속 도는 정확성에 비해 뚜렷한 발달적 진전이 관찰되지 않았다. 마 지막으로 반응의 일관성은 3세와 4세 사이에 유의미한 향상이 나타났으며, 4세부터 $\mathrm{DDK}$ 과제에 대해 정확하고 일관적인 반 응이 관찰되었다. 이러한 연구는 말소리 습득이 아직 완전하게 이루어지지 않은 아동을 대상으로 초당 반복 횟수로 측정하는 속도뿐만 아니라 일관성과 정확도 측면도 평가하는 것이 아동 의 말운동 능력을 살펴보는 데 보다 더 타당함을 제안하고 있 다. 따라서 숙련된 임상가의 청지각적 판단을 통해 DDK 과제 수행 시 규칙성, 정확도, 속도를 보완적으로 평가하는 것이 유 용할 수 있다.

말운동 능력의 발달적 변화를 이해하기 위해서는 아동의 연 령에 따른 DDK 수행력 변화뿐만 아니라 성인의 수행력과 비 교하는 것도 궁극적으로 필요하다. 즉 아동의 말운동 기술이 전체적인 말운동 발달과정에서 최고치에 해당하는 성인 수준 의 안정적인 말운동 능력과 비교하여 어느 수준에 위치해 있는 지를 파악하는 것이 중요하다. 2 73세를 대상으로 한 Choe \& $\mathrm{Han}(1998)$ 연구에서도 아동의 연령이 증가할수록 $\mathrm{AMR}$ 이 증 가하였다. 그러나 장년층 이후부터는 감소하는 경향을 보였다. 한편, 10 12세에 해당하는 초등학교 고학년과 18 39세에 해당 하는 청년층 간의 과제에 따른 반복 횟수는 유의미한 차이를 보이지 않았다. 따라서, 초등학교 고학년에 이르러서야 수행력 이 청년층과 유사한 안정적인 말운동 능력을 갖추게 된다고 볼 수 있다. 그러나 대상자를 유아층, 학령 전 아동층, 초등 저학년 층, 초등 고학년층, 청년층, 장년층, 노년층으로 나누어 살펴보아 상대적으로 발달이 빠르게 이루어지는 학령전기 아동들의 수 행력을 면밀히 파악하기는 어려웠다. 또한 2 3세의 어린 아동 을 대상으로 말운동 기술의 발달적 변화를 살펴본 연구가 부족 한 실정이다. 따라서 초기 발달 단계에 있는 2 3세의 어린 연령 을 포함하여 아동의 연령 집단을 좀 더 세밀하게 나누어 발달 이 완성이 된 성인의 수행력과 비교하면서 말운동 기술의 발달 적 변화를 살펴볼 필요가 있다.

대다수의 국내 선행 연구에서 $\mathrm{DDK}$ 검사어는 기식음을 주로
사용하여, $\mathrm{AMR}$ 과제에서 1음절 $\mathrm{CV}$ 검사어로 [퍼], [터], [커]와 $\mathrm{SMR}$ 과제에서 2 3음절 $\mathrm{CVCV}$ 와 $\mathrm{CVCVCV}$ 검사어로 [퍼터], [퍼터커]를 사용하였다(Choi \& Yoo, 2018; Sehr, 2013; Yoo, 2018). 국내 아동을 대상으로 말 산출 하위기제와 말운동 문제를 보이는 아동을 선별하기 위해 개발된 조음기관 구조-기능 선별 검사(Speech Mechanism Screening Test for Children) (Kim et al., 2018)의 하위 영역 중 하나인 $\mathrm{DDK}$ 의 검사어를 살펴보면 위와 유사하게 [퍼], [터], [커], [러], [겅], [퍼터커]를 사용하였다 (Kim \& Kim, 2016; Kim et al., 2018; Kim, 2019). 국내에서 $\mathrm{DDK}$ 검사어로 기식음이 일반적으로 사용되는 이유는 영어권 국가에서 사용되는 $\mathrm{DDK}$ 검사어를 참조한 것과 관련이 있다.

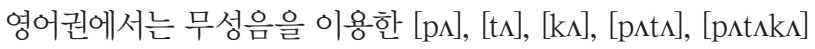
검사어를 말운동장애 평가를 위한 $\mathrm{DDK}$ 과제로 보편적으로 사용하고 있다. 영어에서는 무성음이 유성음보다 동일한 조음 위치와 방법 내에서 보다 일찍 습득되고 산출하기가 상대적으 로 쉬운 소리에 해당한다(Berthal et al., 2013). 한국어 파열음 중 기식음은 영어의 무성음과 유사하게 들리나 기식 구간으로 인해 파열음 가운데에서는 상대적으로 어려운 소리에 해당하 여 아동은 발달적으로 기식음을 경음과 평음보다 늦게 습득한 다(Kim \& Pae, 2005). 앞서 언급한 바와 같이 DDK 과제에서 조음 오류 빈도와 유형을 살펴본 $\operatorname{Sehr}(2013)$ 의 연구에서 4세 아동의 경우에도 기식음을 평음이나 경음으로 빈번하게 오조 음하는 것으로 나타났다. 기식음으로 구성된 검사어를 사용할 경우 4 세 이하의 어린 아동의 경우는 목표 음절을 정확하게 산 출하는 데 상대적으로 어려움을 보여 DDK 속도와 규칙성을 평가하는 데 타당성이 떨어질 수 있다. 따라서 어린 아동을 대 상으로 조음기관의 말운동 능력을 보다 더 타당하게 평가하기 위해서는 조음 난이도가 상대적으로 낮아 일찍 습득되는 경음 이나 평음을 사용하는 것이 적절하다.

본 연구는 일반 발달을 보이는 만 2세 후반 9세 아동과 20대 정상 성인을 대상으로, 경음으로 구성된 $\mathrm{AMR}$ 과제(1음절)과 $\mathrm{SMR}$ 과제(2, 3음절)를 실시하였다. 초당 반복 횟수를 토대로 $\mathrm{AMR}$ 과 SMR 과제의 속도를 정량적으로 측정함과 동시에 청 지각적인 평가를 바탕으로 규칙성, 속도, 정확도 면에서의 연령 에 따른 변화를 살펴보았다.

\section{MATERIALS AND METHODS}

\section{Participants}

본 연구의 대상자는 전국(서울, 경기, 강원, 충청, 전라, 경상) 에 거주하는 만 2세 후반 9세 아동과 만 20대 청년층에 해당하 는 성인이다. 조음음운 능력이 급격하게 발달하는 2 6세 아동 의 경우 그 발달과정을 민감하게 살펴보고자 6 개월 단위로 연 
령 집단을 구분하였고, 7 9세는 1년 단위로 나누어 비교 분석 하였다. 일부 아동은 특정 검사어 수행에 어려움을 보이거나 실시를 거부하여 일부 검사어만 연구 자료에 포함되었다. 따라 서 검사어별로 참여 대상자의 전체 수가 상이하다. 본 연구에 서 사용한 검사어는 [빠], [따], [까], [빠따], [빠따까]로 총 5개이 며, 검사어 [빠]를 기준으로 하였을 때 대상자 중 과제 절차를 이해하고 실시 가능하였던 아동은 333 명, 성인은 20명으로 총 353 명이다. 분석에 포함된 검사어별 대상자 수는 Table 1과 같 다. 일반 아동은 아동용 발음평가(Assessment Phonology and Articulation for Children, APAC) (Kim et al., 2007) 결과 백 분위 수 $16 \%$ ile 이상에 해당하고, 한국 조음음운프로파일 $\left(\mathrm{Ko}^{-}\right.$ rean Articulation Phonology Profile, K-APP) (Ha et al., 2019)의 part I, II 검사 결과 구강구조 및 기능의 문제가 없었으 며, 부모 및 교사로부터 인지적, 감각적, 청각적 문제가 없다고 보고받은 아동에 해당한다. 점막하구개열, 자폐범주성장애, 지 적장애 등과 같이 다른 장애를 동반하는 아동, 시각장애와 같 이 신체적 문제를 보이는 아동, attention-deficit/hyperactivity disorder (ADHD)이거나 관련된 약물을 복용하고 있는 아동 은 대상자에서 제외하였다. 성인은 K-APP의 part I, II 검사 결 과 구강구조 및 기능의 문제가 없었으며, 본인으로부터 인지적, 감각적, 청각적 문제가 없다고 보고받았다.

\section{Data collection}

자료 수집은 K-APP의 조음기관 기능 중 3단계인 '조음교대 운동 검사의 절차를 따랐다. 검사어는 총 5개로 CV 3개([빠], [따], [까]), CVCV 1개([빠따]), CVCVCV 1개([빠따까])로 이루 어져 있다. 검사 실시 전 모든 대상자에게 검사어를 한 호흡에 정확하고 빠르게 산출하도록 요구하였다. 대상자는 검사자가

Table 1. Examination terms and the number of participants by age

\begin{tabular}{lrrrcc}
\hline Age groups & {$\left[\mathrm{p}^{*} \mathrm{a}\right]$} & {$\left[\mathrm{t}^{*} \mathrm{a}\right]$} & {$\left[\mathrm{k}^{*} \mathrm{a}\right]$} & {$\left[\mathrm{p}^{*} \mathrm{at}^{*} \mathrm{a}\right]$} & {$\left[\mathrm{p}^{*} \mathrm{at}^{*} \mathrm{ak}\right.$ a $]$} \\
\hline $2 ; 6-2 ; 11$ & 16 & 16 & 15 & 14 & 13 \\
$3 ; 0-3 ; 5$ & 26 & 26 & 26 & 25 & 23 \\
$3 ; 6-3 ; 11$ & 26 & 25 & 26 & 25 & 21 \\
$4 ; 0-4 ; 5$ & 24 & 24 & 24 & 22 & 20 \\
$4 ; 6-4 ; 11$ & 33 & 32 & 33 & 31 & 27 \\
$5 ; 0-5 ; 5$ & 41 & 41 & 41 & 37 & 32 \\
$5 ; 6-5 ; 11$ & 20 & 20 & 20 & 19 & 15 \\
$6 ; 0-6 ; 5$ & 18 & 18 & 18 & 17 & 13 \\
$6 ; 6-6 ; 11$ & 23 & 22 & 23 & 22 & 22 \\
$7 ; 0-7 ; 11$ & 49 & 50 & 50 & 50 & 48 \\
$8 ; 0-8 ; 11$ & 41 & 42 & 42 & 42 & 41 \\
$9 ; 0-9 ; 11$ & 14 & 14 & 14 & 14 & 14 \\
$20 ; 0-27 ; 11$ & 20 & 20 & 20 & 20 & 20 \\
Total & 351 & 350 & 352 & 338 & 309 \\
\hline & & & & &
\end{tabular}

제시한 모델링을 따라 1 2회 연습한 후 검사를 실시하였다. 본 검사에서는 검사어별로 3회씩 산출할 기회가 주어졌다. 대상자 의 산출은 음성 녹음기(SONY ICD-PX440, Sony corporation, Beijing, China)를 사용하여 녹음하였다.

\section{Data analysis}

언어병리학 전공생 18 명이 녹음 파일을 토대로 $\mathrm{DDK}$ 의 초당 반복 횟수 분석을 1 차로 실시하였다. 분석은 Adobe Audition 1.5 프로그램(Adobe Systems Inc., San Jose, CA, USA)을 사 용하였다. 분석을 시작하기 전 저자들은 언어병리학 전공생 18 명을 대상으로 Adobe Audition 1.5 프로그램에서 분석 구간을 지정해서 지속 시간과 파형의 수를 측정하여 초당 반복 횟수를 계산하는 방법에 대해 훈련을 실시하였다. 언어병리학 전공생 18 명이 1 차적으로 분석한 모든 자료를 제 1 저자와 제 2 저자가 재 검토하면서 최종 분석값을 정리하였다.

Cohen \& Waters(1999)의 연구에서 음운지연 아동과 일반 아동의 $\mathrm{DDK}$ 의 반복 횟수를 비교하였을 때 정확한 산출의 포 함 여부에 따라 결과가 상이하였다. 정확한 산출만 포함하였을 때는 두 아동 집단 간의 차이가 나타났으나 부정확한 산출까지 포함하여 아동의 모든 산출을 분석했을 때는 집단 간의 차이 가 없었다. 따라서 본 연구에서는 과제에 포함된 자음을 부정 확하게 산출한 아동의 자료는 반복 횟수 분석에서 제외하였다. 예를 들어 아동이 [빠]를 [파]로 산출했을 경우는 분석에서 제 외하였다. 각 검사어별로 3 회씩 산출한 자료를 모두 분석하여 평균값을 아동의 초당 반복 횟수로 최종 처리하였다.

$\mathrm{DDK}$ 의 청지각적 평가는 제 1 저자와 제 2 저자가 독립적으로 아 동의 녹음 파일을 듣고 3점 척도를 이용하여 규칙성, 속도, 정확 성 면에서 진행하였다. 규칙성은 일정한 간격으로 검사어를 산 출하는지, 속도는 음절 반복이 느리거나 빠르지 않은지, 정확성 은 검사어를 정확하게 조음하는지를 평가하였다. 대상자가 검사 어별로 3회씩 산출한 결과를 끝까지 듣고 평균적인 수행력을 기 준으로 판단하였으며, 주변 소음으로 인해 3 개의 평가 기준 중 하나라도 평가하기 어렵다고 판단되는 경우는 청지각적 분석에 서 제외하였다. 검사어별로 규칙성, 속도, 정확도 점수를 3점 체 계로 0 (비정상적), 1 (정상에서 조금 벗어남), 또는 2(정상적)점을 부여한 뒤 $\mathrm{AMR}$ 과 $\mathrm{SMR}$ 별로 점수를 합산하였다. $\mathrm{AMR}$ 에는 검 사어 [빠], [따], [까가 해당되며 AMR 규칙성, 속도, 정확도의 만점은 각 6점씩이다. SMR은 검사어 [빠따], [빠따까가 해당되 며 SMR 규칙성, 속도, 정확도의 만점은 각 4점씩이다.

반복 횟수의 검사자 간 신뢰도는 언어병리학 전공생 18 명이 1 차적으로 분석한 모든 자료를 제 1 저자와 제 2 저자가 재검토하 면서 검증하였다. Pearson 상관분석을 이용하여 언어병리학 전 공생과 저자 간의 신뢰도를 산출한 결과 [빠]는 0.979, [따]는 
0.992, [까]는 0.983, [빠따]는 0.897 그리고 [빠따까]는 0.993으 로 모두 유의수준 $p<0.01$ 로 유의하였다. 청지각적 평가의 평 가자 간 신뢰도 분석은 전체 자료의 약 $10 \%$ 에 해당하는 34 명의 자료를 토대로 검사어별 규칙성, 속도, 정확도의 두 검사자 간 일 치율을 살펴보았다. 제 1 저자와 제 2 저자의 일치율은 88.24 $100 \%$ 였다.

\section{Statistical analysis}

수집된 결과는 SPSS version 25.0 (IBM Corp., Armonk, NY, USA) 소프트웨어를 이용하여 분석하였다. 본 연구에서는 연령 집단에 따른 $\mathrm{DDK}$ 반복 횟수와 청지각적 특성을 비교하 기 위해 일원분산분석[one-way analysis of variance (ANO$\mathrm{VA})$ ]을 실시하였다. 연령집단에 따른 유의한 차이가 있는 경우 에는 유의수준값을 교정하기 위해 Bonferroni 검정으로 사후 분석을 실시하였다. 분석의 유의수준은 모두 $p<0.05$ 로 정하 였으며, 효과크기는 부분에타제곱값 $\left(\eta_{\mathrm{p}}^{2}\right)$ 으로 측정하였다.

\section{RESULTS}

\section{DDK rate}

연령에 따른 $\mathrm{DDK}$ 초당 반복 횟수의 평균과 표준편차는 $\mathrm{Ta}-$ ble 2 와 같다. AMR 과제 중 검사어 [빠]와 [따]의 초당 반복 횟 수는 2세 후반 3세 후반이 약 3.5 회, 4세 전반 7세가 약 4회, 8세 와 9 세는 4.5 회, 성인은 약 5.6 회로 나타났다. [까]의 경우 2세 후반 3세 후반은 약 3.5회, 4세 전반 6세 후반은 약 4회, 7 9세 는 약 4.5회, 성인은 약 5.6회로 나타났다. SMR 과제 중 검사어 [빠따]의 초당 반복 횟수는 2 세 후반이 약 1.5 회, 3 세 전후반이 약 2회, 4세 전반 9 세가 약 2.5 회, 성인이 약 3 회로 나타났다.
검사어 [빠따까]의 경우에는 2 세 후반 4세 전반까지 약 1 회, 4 세 후반 9 세까지 약 1.5 회, 성인은 약 2 회로 나타났다.

일원분산분석(one-way ANOVA) 결과 $[$ 빠 $][\mathrm{F}(12,341)=$ 23.524, $\left.p<0.05, \eta_{\mathrm{p}}{ }^{2}=0.462\right]$, [따][F(12, 335) $=25.424, p<$ $\left.0.05, \eta_{\mathrm{p}}{ }^{2}=0.486\right],[$ 까 $]\left[\mathrm{F}(12,343)=24.964, p<0.05, \eta_{\mathrm{p}}{ }^{2}=\right.$ 0.475 ], [빠따] [F(12, 310 $=12.224, p<0.05, \eta_{\mathrm{p}}^{2}=0.330$ ], [빠따 까 $\left[\mathrm{F}(12,217)=15.545, p<0.05, \eta_{\mathrm{p}}^{2}=0.476\right]$ 과제 모두 연령 에 따라 유의미한 차이가 있었다. 사후 분석 Bonferroni 결과, 검사어 [빠]는 2세 후반은 5세 전반과 6세 후반, 7세, 8세, 9세, 성인과 유의한 차이가 있었으며, 3세 전반은 4세 후반, 5 세 전 후반, 6세 후반, 7세, 8세, 9세, 성인과 유의한 차이가 있었다. 3세 후반은 4세 전반 성인까지 모든 집단과, 4세 전후반은 각각 8 세와 성인, 5 세 전반 9세는 각각 성인과 유의미한 차이를 보였 다. [따]는 2 세 후반과 3 세 후반의 경우 4 세 전반 성인까지 모 든 집단과 유의한 차이가 있었고, 3세 전반은 5세 전후반, 6 세 전반, 7세, 8세, 9세, 성인과, 4세 후반은 8세, 성인과 유의한 차 이가 있었다. 4세 전반과 5세 전반 모든 연령 집단은 성인 사이 에만 유의미한 차이가 있었다. [까]는 2세 후반 3세 후반까지 는 각각 5세 전후반, 6세 후반, 7세, 8세, 9세, 성인과 유의한 차 이고 있었고, 4세 전반과 5 세 전반은 8세, 성인과 유의한 차이가 있었다. 4세 후반과 7세, 8세, 성인과 유의한 차이가 있었고, 5 세 후반 모든 연령 집단은 성인 집단과만 유의미한 차이를 보였다. [빠따]는 2세 후반의 경우 4세 전반 성인까지, 3 세 전후반은 각 각 8세와 성인, 4세 전반 모든 연령 집단은 성인 사이에만 유의 미한 차이를 보였다. [빠따까]는 2세 후반의 경우 5 세 후반, 6 세 전후반, 7세, 8세, 성인과, 3세 후반은 5세 후반, 6세 후반, 7세, 8세 성인과 유의한 차이가 있었다. 3 세 전반, 4 세 전후반, 5 세 전반은 각각 8세, 성인과 유의한 차이가 있었고, 5 세 후반 모든 연령 집

Table 2. Descriptive statistics of diadochokinesis rate by age groups (per/s)

\begin{tabular}{|c|c|c|c|c|c|c|c|c|c|c|}
\hline \multirow{2}{*}{ Age groups } & \multicolumn{2}{|c|}{$\left[\mathrm{p}^{*} \mathrm{a}\right]$} & \multicolumn{2}{|c|}{$\left[\mathrm{t}^{*} \mathrm{a}\right]$} & \multicolumn{2}{|c|}{$\left[\mathrm{k}^{*} \mathrm{a}\right]$} & \multicolumn{2}{|c|}{ [p*at*a] } & \multicolumn{2}{|c|}{ [p*at*ak*a] } \\
\hline & Mean & $\mathrm{SD}$ & Mean & $\mathrm{SD}$ & Mean & $\mathrm{SD}$ & Mean & $\mathrm{SD}$ & Mean & $\mathrm{SD}$ \\
\hline $2 ; 6-2 ; 11$ & 3.54 & 0.43 & 3.38 & 0.55 & 3.36 & 0.35 & 1.69 & 0.64 & 0.94 & 0.45 \\
\hline $3 ; 0-3 ; 5$ & 3.51 & 0.69 & 3.55 & 0.55 & 3.47 & 0.66 & 2.05 & 0.42 & 1.21 & 0.34 \\
\hline $3 ; 6-3 ; 11$ & 3.41 & 0.48 & 3.42 & 0.44 & 3.48 & 0.50 & 2.07 & 0.39 & 1.09 & 0.33 \\
\hline $4 ; 0-4 ; 5$ & 4.01 & 0.49 & 4.14 & 0.55 & 3.87 & 0.51 & 2.26 & 0.36 & 1.26 & 0.42 \\
\hline $4 ; 6-4 ; 11$ & 4.07 & 0.48 & 4.06 & 0.57 & 3.89 & 0.45 & 2.27 & 0.37 & 1.38 & 0.39 \\
\hline $5 ; 0-5 ; 5$ & 4.20 & 0.61 & 4.27 & 0.57 & 3.94 & 0.51 & 2.37 & 0.39 & 1.40 & 0.36 \\
\hline $5 ; 6-5 ; 11$ & 4.20 & 0.58 & 4.27 & 0.58 & 4.06 & 0.42 & 2.36 & 0.39 & 1.53 & 0.17 \\
\hline $6 ; 0-6 ; 5$ & 4.06 & 0.48 & 4.27 & 0.56 & 3.99 & 0.51 & 2.44 & 0.33 & 1.50 & 0.26 \\
\hline $6 ; 6-6 ; 11$ & 4.21 & 0.71 & 4.12 & 0.76 & 4.04 & 0.65 & 2.28 & 0.43 & 1.52 & 0.29 \\
\hline $7 ; 0-7 ; 11$ & 4.38 & 0.59 & 4.48 & 0.60 & 4.32 & 0.55 & 2.37 & 0.38 & 1.58 & 0.27 \\
\hline $8 ; 0-8 ; 11$ & 4.57 & 0.59 & 4.59 & 0.61 & 4.36 & 0.57 & 2.48 & 0.38 & 1.73 & 0.38 \\
\hline $9 ; 0-9 ; 11$ & 4.51 & 0.57 & 4.50 & 0.76 & 4.28 & 0.24 & 2.35 & 0.30 & 1.45 & 0.23 \\
\hline $20 ; 0-27 ; 11$ & 5.78 & 0.69 & 5.95 & 0.72 & 5.64 & 0.61 & 3.15 & 0.33 & 2.25 & 0.22 \\
\hline
\end{tabular}

SD: standard deviation 
단은 성인 집단과만 유의미한 차이를 보였다 $(p<0.05)$.

\section{DDK perceptual judgment}

연령에 따른 $\mathrm{DDK}$ 청지각적 평가의 평균과 표준편차는 $\mathrm{Ta}-$ ble 3 과 같다. 청지각적 평가는 검사어 [빠], [따], [까]를 통한 AMR과 검사어 [빠따], [빠따까]를 통한 SMR별로 규칙성, 속 도, 정확도 점수를 구하였다. 평가 항목별로 6점이 최고점인 $\mathrm{AMR}$ 은 가장 연령이 어린 2세 후반 아동도 규칙성, 속도, 정확 도의 모든 항목에서 약 5.8점을 받아 높은 수행력을 보이는 것 으로 나타났다. 평가 항목별로 4점이 최고점인 SMR은 2세 후 반 아동은 규칙성과 속도 면에서 약 3.7로 높은 연령대 아동과 거의 비슷한 수행력을 보였으나 정확도 면에서는 2세 후반에서 3세 전반까지 2.5점대, 3세 후반부터 6세 전반까지 3점대, 6세 후 반에서 9세까지는 3.7점대, 성인은 4점의 수행력을 보여 연령이 증가할수록 정확도가 점진적으로 증가하는 것으로 나타났다.

일원분산분석(one-way ANOVA) 결과 검사어 [빠], [따], [까]를 통한 AMR의 규칙성, 속도, 정확도는 모두 연령 집단 간 유의미한 차이를 보이지 않았다. 반면에 검사어 [빠따], [빠따 까]를 통한 $\mathrm{SMR}$ 의 경우에는 규칙성 $[\mathrm{F}(12,093)=2.475, p<$ $\left.0.05, \eta_{\mathrm{p}}^{2}=0.084\right]$, 속도 $\left[\mathrm{F}(9.380)=2.039, p<0.05, \eta_{\mathrm{p}}{ }^{2}=0.070\right]$, 정확도 $\left[\mathrm{F}(48.987)=8.425, p<0.05, \eta_{\mathrm{p}}{ }^{2}=0.239\right]$ 모두 연령 집단 간 유의미한 차이를 보였다. 사후 분석으로 Bonferroni 검정 결
과, $\mathrm{SMR}$ 의 정확성에서만 일부 연령 집단 간 다중비교에서 유의 미한 차이를 보였다. SMR의 정확성은 2세 후반, 3세 전반과 4세 후반은 각각 6세 후반, 7세, 8세, 9세, 성인과 유의한 차이가 있었으며, 3세 후반은 6세 후반, 7세, 성인과 유의한 차이를 보였 다. 4 세 전반, 5 세 전후반과 6 세 전반은 각각 성인 집단과만 유 의미한 차이를 보였다 $(p<0.05)$.

\section{DISCUSSIONS}

본 연구는 $\mathrm{DDK}$ 수행력을 통해 말운동 능력의 발달 과정을 살펴보고자 만 2세 후반 9세의 일반 아동과 20대 성인을 대상 으로 AMR과 SMR 과제의 반복 횟수와 청지각적 특성을 연령 별로 살펴보았다. 연구 결과, 2 세 후반 9세까지 연령이 높아질 수록 DDK 반복 횟수가 증가하는 것으로 나타나, 아동을 대상 으로 주어진 시간 동안 산출한 음절 수를 토대로 초당 반복 횟 수를 살펴본 대다수의 선행 연구와 일관성있는 결과를 보여주 었다(Choe \& Han, 1998; Fletcher, 1972; Kim \& Kim, 2016; Kim et al., 2018; Robbins \& Klee, 1987; Sehr, 2013; Williams \& Stackhouse, 2000; Yoo, 2018; Yoss \& Darley, 1974).

영어권 문헌에서는 무성 파열음을, 국내 문헌에서는 대부분 기식음을 사용하였기 때문에 경음을 사용한 본 연구 결과와 직접적인 비교는 제한적이다. 하지만 초당 반복 횟수로 측정한

Table 3. Descriptive statistics of diadochokinesis perceptual judgment scores by age groups

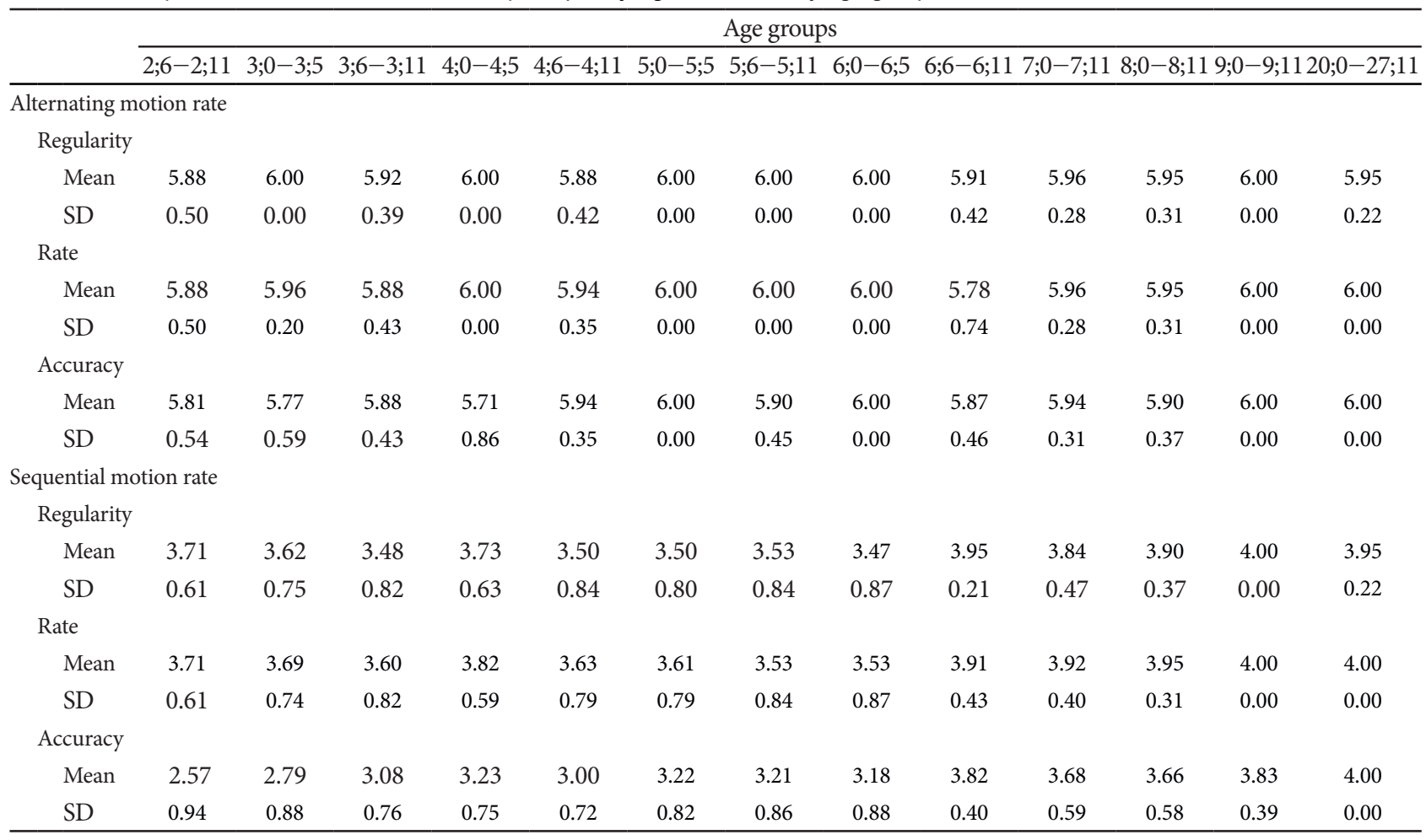

SD: standard deviation 
$\mathrm{AMR}$ 과 SMR의 연령별 결과는 국내외 연구 결과와 비슷한 수 치로 나타났다. 본 연구에서는 [빠]에 대한 AMR은 6세 전반에 서 초당 4.06회, 7세에서 4.38회, 8세에서 4.57회, 9세에서 4.51회 로 나타났다. 예를 들어 Fletcher(1972)의 연구에서는, [퍼]에서 6세와 7세는 초당 4.2회, 8세는 4.8회, 9세는 4.4회로 나타나 본 연구와 전반적으로 유사한 결과를 보였다. 두 번째로 [따]에서 본 연구 결과 6 세 전반에서 4.27 회, 7 세에서 4.48 회, 8 세에서 4.59회, 9세에서 4.50회로 나타났다. Fletcher(1972)의 연구에서 도 [터]의 경우 6세와 7세는 4.1회, 8세는 4.5회, 9세는 4.9회로 나타나 유사한 결과를 보였다. 세 번째로 [까에서 본 연구 결과 6세 전반에서 초당 3.99회, 7세에서 4.32회, 8세에서 4.36회, 9세 에서 4.28회로 나타났다. Fletcher(1972)의 연구에서는 [커]의 경우 6세 3.6회, 7세 3.8회, 8세 4.2회, 9세 4.3회로 보고하였다. 본 연구의 1 음절 AMR 과제의 초당 반복 횟수는 4 6세를 대상 으로 성별에 따른 DDK 속도를 살펴본 국내 연구인 $\mathrm{YoO}(2018)$ 의 결과와도 거의 비슷한 수치를 보였다. 마지막으로 본 연구에 서 [빠따까]를 이용하여 SMR을 살펴본 결과, 6세 전반에서 초 당 1.50 회, 7 세에서 1.58 회, 8 세에서 1.73 회, 9 세에서 1.45 회로 나 타났다. Yoss \& Darley(1974)는 [퍼터커] 과제에서 5세 1.14회, 6세 1.26회, 7 9세 1.28회로 보고해, 본 연구보다는 초당 반복 횟 수가 작지만 전반적으로 유사한 결과가 나타났다. 종합적으로 본 연구와 선행 연구(Fletcher, 1972; Yoo, 2018; Yoss \& Darley, 1974)의 초당 반복 횟수를 비교해보았을 때 자음의 발성 유형 과 모음면에서 검사어가 서로 상이하지만 아동 연령별로 비슷 한 $\mathrm{AMR}$ 과 $\mathrm{SMR}$ 의 수행력을 보이는 것으로 나타났다.

본 연구에서 $\mathrm{AMR}$ 과 SMR 과제의 검사어별로 약간의 차이 는 있지만 2세 후반 4세 후반 또는 5세 전반까지 높은 연령대 (6 9세)의 아동과 수행력의 차이를 보이다가 이후 높은 연령대 는 서로 유의한 차이를 보이지 않았다. 그러나 AMR과 SMR 과 제 모두 성인과 비교해 모든 연령대의 아동이 유의하게 낮은 반 복 횟수를 보여, 9 세에 이르러서도 성인 수준의 말운동 기술을 갖추지 못하는 것으로 나타났다. 이러한 결과는 8 11세까지도 성인 수준의 산출 속도와 일관성에 도달하지 않는다는 Kent \& Forner(1980)의 연구와 일관성이 있다. 추가적으로 성인과 아 동의 DDK 수행력을 비교한 선행 연구를 살펴보면, Canning \& Rose(1974)는 9 10세 혹은 15세 정도가 되어야 성인과 유사한 반복 횟수를 산출한다고 보고하였다. Choe \& Han(1998)은 10 12세에 해당하는 초등학교 고학년에 이르러 19 39세 청년 층과 같은 반복 횟수를 보인다고 보고하였다. 따라서 본 연구와 선행 연구의 결과를 종합해보면 DDK 속도는 2세 후반 9세까 지 아동기 전반에 걸쳐서 발달하고 초등학교 고학년 이후에 성 인 수준의 말운동 속도를 갖춘다고 할 수 있다.

본 연구에서는 초당 반복 횟수를 토대로 $\mathrm{DDK}$ 속도를 정량
적으로 측정한 결과뿐만 아니라 음성 자료를 듣고 청지각적으 로 규칙성, 속도, 정확성을 평가한 결과도 제시하였다. 초당 반 복 횟수는 정량적인 수치로 객관적인 비교가 가능하다는 장점 이 있지만 실제 임상에서 측정할 때는 파형과 같은 음향학적 신호를 시각적으로 확인하면서 정확하게 분석하는 것이 필요 해서 편리성과 유용성이 떨어지기도 한다. 실제로 반복 횟수보 다는 평가 대상자의 음성을 듣고 임상가가 규칙성, 속도, 정확 성, 협응 정도를 청지각적으로 판단하여 말운동 능력을 평가하 는 것이 보다 더 효율적일 수 있다. 청지각적 평가 결과를 살펴 보았을 때 AMR 과제에서의 규칙성, 속도, 정확도 면에서 모두 연령에 대한 주 효과는 나타나지 않았다. 이러한 결과는 청지각 적 평가 내용이 얼마나 규칙적인지, 또는 얼마나 빠르고 정확한 지를 판단하는 것이 아니라 조음기관 움직임의 규칙성, 속도, 정확도가 정상적인 말 발달과 비교하여 허용할 수 있는 범위에 있는지를 판단하는 과제였기 때문이다. 즉 조음기관의 단순한 반복적인 움직임만을 필요로 하는 AMR 과제의 규칙성, 속도, 정확도는 2세 후반부터 정상적인 수준을 보이는 것으로 청지각 적으로 판단되었다.

반면에 SMR 과제는 규칙성, 속도, 정확도 면에서 모두 연령 에 대한 주 효과가 나타났다. 사후 분석 결과 규칙성과 속도 면 에서는 연령에 대한 효과 크기가 크지 않아, 연령 집단별 대응 비교 시 유의수준에 도달한 집단은 없었다. 하지만 정확도의 경우에는 2세 후반 4세 후반은 6 세 후반 이후 높은 연령대의 아동과 성인과 유의한 차이를 보였다. 5세 전반과 6세 전반까지 는 성인과 여전히 유의한 차이를 보이다가, 6 세 후반부터는 성 인과 유의한 차이를 보이지 않았다. SMR 과제의 청지각적 평 가 결과를 종합하면 서로 다른 조음기관을 연속적으로 빠르게 열고 닫는 움직임의 규칙성, 속도, 정확도는 아동기 전반에 걸 쳐 발달하여 점진적으로 정상 범위에 도달하였다. SMR 과제 의 규칙성, 속도, 정확도 중에서 정확도가 발달적 차이를 가장 뚜렷하게 보였다. 2세 후반과 4세 후반은 서로 다른 조음위치에 서 산출되는 일련의 자음을 연속적으로 정확하게 산출하는 것 이 어려워 조음 오류를 보이는 경우가 많았다. 5세 전반부터는 아직 성인 수준까지는 도달하지 못했지만 조음 오류가 감소하 여 높은 연령대와 같은 수행력을 보이다가 6세 전반에 이르러 성인과 같은 정확도를 보였다. 이러한 결과는 $\mathrm{DDK}$ 과제를 속 도와 정확도 측면에서 살펴본 선행 연구 결과와 일관성이 있다. 예를 들어 Williams \& Stackhouse(2000)는 연령이 증가함에 따라 $\mathrm{DDK}$ 의 속도보다는 정확도상에서 보다 더 뚜렷한 발달적 진전이 관찰된다고 보고하였다. 또한 4 6세 한국 아동을 대상 으로 DDK를 살펴본 $\operatorname{Sehr}$ (2013)의 연구에서도 조음 오류 빈도 가 4세 아동이 5 세와 6 세 아동에 비해 유의미하게 높았다. 따라 서 $\mathrm{DDK}$ 과제를 토대로 아동의 말운동 능력 발달 수준을 살펴 
볼 때는 속도뿐만 아니라 움직임의 정확도를 포함하여 종합적 으로 평가하는 것이 적절하겠다.

$\mathrm{DDK}$ 과제는 말운동 능력의 일반적인 연령별 발달적 특성을 객관적 수치인 초당 반복 횟수로 정량화하여 관찰할 수 있게 한다. 말운동 능력의 발달적 특성은 초당 반복 횟수의 연령 집 단별 평균을 통해 살펴보는 게 보편적이지만 변이성을 바탕으 로도 살펴볼 수 있다. 아동은 말운동 능력이 증가함에 따라 말 운동 속도가 증가하고 동시에 개인 간 그리고 개인 내 변이성이 감소하면서 안정적인 수행력을 보인다. 예를 들어 Robbins \& Klee(1987)는 2세 6개월 6세 11개월 미국 아동을 대상으로 초 당 반복 횟수를 살펴보았을 때, 3세경에 표준편차가 크게 나타 나 개인차가 크게 나타났다가 점차 감소하는 것으로 나타났다. 본 연구에서도 3세 전반과 후반에서 가장 큰 표준편차가 나타 나 개인차가 큰 연령대인 것으로 나타났다. 또한 본 연구에서 구강 구조 및 기능, 청각, 인지, 말소리 산출상의 문제가 없는 아동만을 대상자로 포함시켰음에도 불구하고 6세 전반과 9세 와 같이 일부 연령대에서 인접한 어린 연령대보다 반복 횟수와 청지각적 평가 결과가 낮아 연령 집단 간 대응비교 사후검정에 서 $\mathrm{DDK}$ 의 발달적 경향성이 명확하지 않은 부분이 있었다. 이러 한 점은 아동의 말운동 능력이 아직 성인 수준에 도달하지 않 아 개인차, 즉 아동 간 변이성을 보이는 표본 집단의 특성이 반 영된 결과라 할 수 있다. 따라서 추후 연구에서는 $\mathrm{DDK}$ 과제의 개인 간 그리고 개인 내 변이성을 체계적으로 분석하여 말운동 능력에 대한 발달적 특성을 면밀하게 살펴볼 필요가 있겠다.

본 연구는 비교적 많은 수의 일반 아동 자료를 토대로 성인 의 수행력과 비교하면서 말운동 능력의 발달 과정을 세밀하게 제시하였다. $\mathrm{DDK}$ 검사어에 주로 사용되는 기식음 대신에 자음 의 발성 유형 중에서 좀 더 일찍 습득되는 경음을 사용하여 2 3세 어린 아동의 말운동 능력도 좀 더 타당하게 볼 수 있도 록 하였다. 또한 초당 반복 횟수 뿐만 아니라 규칙성, 속도, 정확 도 면에서 정상 범위에 속하는지를 청지각적으로 판단한 결과 도 함께 제시함으로써 임상 현장에서 제한된 말운동 기술로 인 해 말소리 산출상의 어려움을 보이는 아동을 선별하고 진단할 때 참조 자료로 사용될 수 있게 하였다. 후속 연구를 통해 다양 한 원인과 심각도, 특성을 보이는 말소리장애 아동의 $\mathrm{DDK}$ 반 복 속도와 청지각적 특성을 살펴보면서 말운동 기술과 말소리 장애와의 관계를 조사하고, 말소리장애 선별 및 진단 검사로서 $\mathrm{DDK}$ 과제의 타당성을 살펴볼 필요가 있겠다.

중심 단어 : 발달 경향 - 조음교대운동 $(\mathrm{DDK})$ - 청지각적 평가 말 운동능력.

\section{Ethical Statement}

This study was approved by the Institutional Review Board of Hallym
University (HIRB-2015-062-2-CM). We explained the purpose and procedures of the study to children's legal guardians or adult participants and obtained their signature on the consent form.

\section{Acknowledgments}

N/A

\section{Declaration of Conflicting Interests}

There are no conflict of interests.

Funding

N/A

\section{Author Contributions}

Conceptualization: Seunghee Ha. Formal analysis: Jisu Jang, Yu Gyeong Choe. Investigation: Jisu Jang, Yu Gyeong Choe. Methodology: Seunghee Ha. Project administration: Seunghee Ha. Resources: Seunghee Ha. Supervision: Seunghee Ha. Validation: Seunghee Ha. Visualization: Jisu Jang, Yu Gyeong Choe. Writing_original draft: Jisu Jang, Yu Gyeong Choe. Writing-review \& editing; Seunghee Ha. Approval of final manuscript: all authors.

\section{ORCID iDs}

Jisu Jang https://orcid.org/0000-0003-1345-5883

Yu Gyeong Choe https://orcid.org/0000-0002-5798-4800

Seunghee Ha https://orcid.org/0000-0001-5576-2895

\section{REFERENCES}

Baken, R. J. \& Orlikoff, R. F. (2000). Clinical Measurement of Speech and Voice. San Diego, CA: Singular Publishing Group.

Bernthal, J. E., Bankson, N. W., \& Flipsen, P. (2013). Articulation and Phonological Disorders: Speech Sound Disorders in Children. Boston, MA: Pearson.

Canning, B. A. \& Rose, M. F. (1974). Clinical measurements of the speed of tongue and lip movements in British children with normal speech. The British Journal of Disorders of Communication, 9(1), 45-50.

Choe, J. \& Han, J. S. (1998). Diadochokinetic rate of normal children and adults: a preliminary study. Communication Sciences and Disorders, 3(1), 183-194.

Choi, A. R. \& Yoo, J. Y. (2018). The Characteristics of Diadochokinesis in 1st and 2nd Grades of Elementary School Students. Journal of Rehabilitation Research, 22(2), 231-246.

Cohen, W. M \& Waters, D. (1999). Measuring speech motor skills in normally developing and phonologically disordered pre-school children. Proceedings of 14th International Congress of Phonetic Sciences (pp. 789-792). San Francisco, CA, USA.

Fletcher, S. G. (1972). Time-by-count measurement of diadochokinetic syllable rate. Journal of Speech and Hearing Research, 15(4), 763-770.

Ha, S., Kim, M., \& Pi, M. (2019). Percentage of consonants correct and age of acquisition of consonants in Korean-speaking children in one-syllable word contexts. Communication Sciences and Disorders, 24(2), 460468.

Kent, R. D. \& Forner, L. L. (1980). Speech segment durations in sentence recitations by children and adults. Journal of Phonetics, 8(2), 157-168.

Kim, J. (2019). Discriminating the validity of Speech Mechanism Screening Test for Children for children with speech sound disorders: A ROC curve analysis. Communication Sciences and Disorders, 24(4), 1026-1039.

Kim, J., Shin, M., \& Song, Y. K. (2018). Speech Mechanism Screening Test for Children: an evaluation of performance in 3- to 12-year-old normal developing children. Communication Sciences and Disorders, 23(1), 180-197.

Kim, M. J. \& Pae, S. (2005). The percentage of consonants correct and the 
ages of consonantal acquisition for 'Korean-Test of Articulation for Children (K-TAC)'. Korean Society of Speech Sciences, 12(2), 139-149.

Kim, M., Pae, S., \& Park, C. (2007). Assessment of Phonology and Articulation for Children (APAC). Incheon: Human Brain Research \& Consulting Co.

Kim, Y. S. \& Kim, J. O. (2016). A preliminary study to develop a speech mechanism screening test for preschool children. Journal of SpeechLanguage and Hearing Disorders, 25(3), 105-123.

Robbins, J. \& Klee, T. (1987). Clinical assessment of oropharyngeal motor development in young children. The Journal of Speech and Hearing Disorders, 52(3), 271-277.
Sehr, K. H. (2013). The study of diadochokinetic (DDK) rate and accuracy in typically developing children. Journal of the Korea Academia-Industrial Cooperation Society, 14(1), 321-327.

Williams, P. \& Stackhouse, J. (2000). Rate, accuracy and consistency: diadochokinetic performance of young, normally developing children. Clinical Linguistics and Phonetics, 14(4), 267-293.

Yoo, J. Y. (2018). The Characteristics of Diadochokinesis in Older Preschooler. Journal of Speech-Language and Hearing Disorders, 27(3), 13-21.

Yoss, K. A. \& Darley, F. L. (1974). Developmental apraxia of speech in children with defective articulation. Journal of Speech and Hearing Research, 17(3), 399-416. 